\title{
Physical activity assessment: comparison between movement registration and doubly labeled water method.
}

Citation for published version (APA):

Westerterp, K. R., \& Bouten, C. V. C. (1997). Physical activity assessment: comparison between movement registration and doubly labeled water method. Zeitschrift für Ernahrungswissenschaft, 36(4), 263-267. https://doi.org/10.1007/BF01617795

Document status and date:

Published: 01/01/1997

DOI:

10.1007/BF01617795

Document Version:

Publisher's PDF, also known as Version of record

Document license:

Taverne

Please check the document version of this publication:

- A submitted manuscript is the version of the article upon submission and before peer-review. There can be important differences between the submitted version and the official published version of record.

People interested in the research are advised to contact the author for the final version of the publication, or visit the DOI to the publisher's website.

- The final author version and the galley proof are versions of the publication after peer review.

- The final published version features the final layout of the paper including the volume, issue and page numbers.

Link to publication

\footnotetext{
General rights rights.

- You may freely distribute the URL identifying the publication in the public portal. please follow below link for the End User Agreement:

www.umlib.nl/taverne-license

Take down policy

If you believe that this document breaches copyright please contact us at:

repository@maastrichtuniversity.nl

providing details and we will investigate your claim.
}

Copyright and moral rights for the publications made accessible in the public portal are retained by the authors and/or other copyright owners and it is a condition of accessing publications that users recognise and abide by the legal requirements associated with these

- Users may download and print one copy of any publication from the public portal for the purpose of private study or research.

- You may not further distribute the material or use it for any profit-making activity or commercial gain

If the publication is distributed under the terms of Article $25 \mathrm{fa}$ of the Dutch Copyright Act, indicated by the "Taverne" license above, 
K. R Westerterp

Carlijn V.C. Bouten

\section{Physical activity assessment: Comparison between movement registration and doubly labeled water method}

\begin{abstract}
Abschätzung der körperlichen Aktivität: Vergleich zwischen der Bewegungsregistrierung und der Wasser-Doppelmarkierungsmethode
\end{abstract}

Summary The doubly labeled water method for the measurement of average daily metabolic rate (ADMR), combined with a measurement of resting metabolic rate, permits the calculation of energy expenditure for physical activity under normal daily living conditions. This procedure was used to evaluate the use of movement registration for physical activity assessment under daily living conditions.

Subjects were 16 men and 14 women with normal weight (body mass index (BMI) $24.6 \pm 2.4 \mathrm{~kg} / \mathrm{m}^{2}$ ). Their body movement was registered with a triaxial accelerometer over a 7-day interval, simultaneous with an ADMR measurement with a doubly labeled water method. Resting metabolic rate was measured overnight in a respiration chamber (sleeping metabolic rate (SMR)) at the start of the ADMR

measurement. Subjects did wear the accelerometer during waking hours. Accelerometer output (AO, counts/min) was related to physical activity as quantified by adjustment of ADMR for SMR. Additional studies were performed in 11 subjects with anorexia nervosa (BMI $16.7 \pm 1.7 \mathrm{~kg} / \mathrm{m}^{2}$ ) and 8 subjects with morbid obesity (BMI $45.3 \pm 6.8 \mathrm{~kg} / \mathrm{m}^{2}$ ).

$\mathrm{AO}$ explained most of the variation in ADMR, after adjustment for SMR $\left(\mathrm{R}^{2}=0.64\right.$, $\mathrm{SEE}=0.9 \mathrm{MJ} / \mathrm{d}$ ). Average AO was $1108 \pm 293,1144 \pm 318$, and $946 \pm 391$ for subjects with normal weight, anorexia nervosa, and morbid obesity, respectively, and was not significantly different between the three groups. However, in the anorectics $\mathrm{AO}$ was significantly related to body mass index $(\mathrm{r}=0.84$, $<$ p 0,01), subjects with a BMI17 $\mathrm{kg} / \mathrm{m} 2$ were equally or more active compared with control subjects, while subjects with a BMI $<17 \mathrm{~kg} / \mathrm{m}^{2}$ were equally or less active compared with control subjects. In the morbid obese group, 5 of the 8 subjects had a low activity level $(\mathrm{AO}<900$ counts/day) and the other 3 had a high activity level (AO1150 counts/day).
The triaxial accelerometer is an objective method that can be used to quantify physical activity related energy expenditure and to distinguish differences in activity levels between individuals.

Zusammenfassung Die doppeltmarkierte Wassermethode (DLWM) zur Bestimmung des mittleren täglichen Energieumsatzes (ADMR), kombiniert mit einer Messung des Ruheenergieumsatzes, erlaubt die Berechnung des Energieaufwands für die körperliche Aktivität unter den normalen täglichen Lebensbedingungen. Dieses Verfahren wurde angewandt, um die Anwendung der Bewegungsregistrierung zur $\mathrm{Ab}$ schätzung der körperlichen Aktivität unter den täglichen Lebensbedingungen $z u$ bewerten.

Untersuchungspersonen waren 16 Männer und 14 Frauen mit normalem Gewicht (body mass index BMI $\left.24,6 \pm 2,4 \mathrm{~kg} / \mathrm{m}^{2}\right)$. Thre Körperbewegung wurde mit einem triaxialen Akzelerometer über ein 7-Tages-Intervall registriert, simultan mit einer ADMR-Messung mittels DLWM. Der Ruheenergieumsatz wurde über Nacht in einer Respirationskammer (sleeping metabolic rate SMR) zu Beginn der ADMRMessung bestimmt. Die Probanden trugen das Akzelorometer tagsiiber. Die Quantifizierung der Beziehung zwischen Akzelerometer-Output (AO, Impulse/min) und körperlicher Aktivität wurde durch die An-

\footnotetext{
K. R Westerterp

Carlijn V.C. Bonten
Department of Human Biology

Maastricht University

P. O. Box 616

NL-6200 MD Maastricht

The Netherlands
} 
passung der ADMR an die SMR vorgenommen. Zusätzliche Untersuchungen wurden an 11 Personen mit Anorexia nervosa (BMI $16,7 \pm 1,7 \mathrm{~kg} / \mathrm{m}^{2}$ ) und 8 Personen mit morbider Fettsucht (BMI $45,3 \pm 6,8 \mathrm{~kg} / \mathrm{m}^{2}$ ) durchgeführt. Der AO erklärte die meisten Variationen in der ADMR, nach Justierung auf SMR $\left(R^{2}=0,64, S E E=0,9\right.$ $\mathrm{MJ} / \mathrm{d})$. Der mittlere AO war $1108 \pm 293,1144 \pm 318$ und $946 \pm 391$ für Personen mit Normalgewicht, Anorexia nervosa und morbider Fettsucht. Dieser Wert war nicht signifikant unterschiedlich zwischen den 3 Gruppen. In der Anorexianervosa-Gruppe war der $\mathrm{AO}$ signifikant mit dem BMI korreliert $(\mathrm{r}=0,84, \mathrm{p} \mathrm{0,01)}$. Personen mit $\mathrm{BMI}<17 \mathrm{~kg} / \mathrm{m}^{2}$ waren gleich oder stärker aktiv als die Kontrollpersonen, während Personen mit BMI $\mathrm{kg} / \mathrm{m}^{2}$ gleich oder weniger aktiv als die Kontrollpersonen waren. In der Gruppe der morbiden Übergewichtigen hatten 5 von 8 Personen ein niedriges Aktivitätsniveau (AO < 900 Impulse/d), während die anderen 3 Personen ein hohes Aktivitätsniveau $(\mathrm{AO}>1150 \mathrm{Im}$ pulse/d) aufwiesen. Das triaxiale
Akzelerometer ist eine objektive Methode, um die körperliche Aktivität mit Bezug auf den Energieaufwand zu quantifizieren und Aktivitätsniveaus zwischen den Individuen zu unterscheiden.

Keywords Energy expenditure accelerometer - doubly labeled water method - physical activity human

Schlïsselwörter Energieumsatz Akzelerometer - Wasser-Doppelmarkierungsmethode - körperliche Aktivität - Mensch

\section{Introduction}

The assessment of daily physical activity requires an objective method that can be used under normal daily living conditions, ideally over prolonged intervals of several days or weeks, and with minimal discomfort to subjects. Currently, the doubly labeled water method is generally accepted as the 'gold standard' for physical activity assessment in free-living subjects. This method determines the average daily metabolic rate (ADMR) and - combined with an estimate of resting metabolic rate provides a reliable measure of energy expenditure associated with physical activity over periods of one to three weeks $(8,10,11)$. The doubly labeled water method, however, can only be used to indicate the average level of daily physical activity and does not provide information about activity patterns in time. Furthermore, the high cost of the stable isotopes and the need for sophisticated analysis techniques limit its applicability to small populations. Nevertheless, the method is ideally suited as a reference technique for the evaluation of other methods for physical activity assessment.

Movement registration with body-fixed accelerometers seems to offer promising possibilities to reflect daily physical activity patterns in population studies. The present study was directed at evaluating a triaxial accelerometer for the assessment of daily physical activity in free-living subjects. A portable data unit was used for the on-line recording and storage of accelerometer output over 1 min intervals. Triaxial accelerometer and data unit together are referred to as the Tracmor. The accelerometer consisted of three uniaxial piezoresistive accelerometers, attached to the lower back of the subjects using an elastic belt around the waist, with measurement directions along the antero-posterior, medio-lateral, and longitudinal axis of the trunk.

During a one week period, physical activity was recorded with the Tracmor and compared with ADMR, determined with doubly labeled water and adjusted for sleeping metabolic rate (SMR) as determined in a respiration chamber. Subjects were in the normal body weight range. Subsequently, studies were performed in subjects with anorexia nervosa and in subjects with morbid obesity.

\section{Methods}

\section{Subjects}

Subjects were 16 men and 14 women (body mass index (BMI) $24.6 \pm 2.4 \mathrm{~kg} / \mathrm{m} 2$ ), recruited from a six month follow-up study on the effect of diet composition on energy expenditure (3). Subjects had full time or part time employment with professions varying from office administrator to surgical nurse or dog-trimmer. Most subjects were engaged in leisure time sports activities. Additional studies were performed in 11 subjects with anorexia nervosa (BMI $16.7 \pm 1.7 \mathrm{~kg} / \mathrm{m} 2$ (1)) and 8 subjects with morbid obesity (BMI $45.3 \pm 6.8 \mathrm{~kg} / \mathrm{m} 2$ ). The experimental protocol was approved by the ethics committee of the University of Limburg.

\section{Protocol}

Energy expenditure was measured over a two week interval under normal daily living conditions with doubly labeled water. Dose, sampling protocol, sample analysis, and calculation procedure were as described before (14). Subjects were given a weighed dose of water with a measured enrichment of about 5 atom $\% 2 \mathrm{H}$ and 10 atom $\% 180$ so that baseline levels were increased with $150 \mathrm{ppm}$ for $2 \mathrm{H}$ and $300 \mathrm{ppm}$ for ${ }^{18} \mathrm{O}$. Urine samples for isotope measurement were collected before dosing at night, from the second and last voiding on the next day, and after 7 and 14 days. Isotope abundances in the urine 
samples were measured with an isotope-ratio mass spectrometer (Aqua Sira; VG Isogas). $\mathrm{CO} 2$ production was calculated from isotope elimination rates, as calculated from the slope of the elimination curve, correcting for changes in body water assumed to be proportional to changes in body mass from the start to the end of the observation interval. $\mathrm{CO} 2$ production was converted to average daily metabolic rate (ADMR) using an energy equivalent based on the individual macronutrient composition of the diet (5).

Physical activity was quantificatied by adjustment of ADMR for resting metabolic rate as suggested by Carpenter et al. (4). The measure for resting metabolic rate was sleeping metabolic rate (SMR) observed at night during a $36 \mathrm{~h}$ stay in a respiration chamber at the start of the ADMR measurement. SMR was measured over a 3-hour interval between 1.00 and 7.00 AM with the minimal activity level judged from Doppler radar observation. Subsequently, subjects did wore a triaxial accelerometer (2) over a 7-day interval, i.e., the first week of the two-week ADMR measurement. The accelerometer consisted of three uniaxial piezoresistive accelerometers, attached to the lower back of the subjects using an elastic belt around the waist with measurement directions along the antero-posterior, medio-lateral, and longitudinal axis of the trunk. A flexible cable ran from the accelerometer to a portable unit $(110 \times 70 \times 35 \mathrm{~mm}, 250 \mathrm{gram})$ for on-line acquisition, processing, and storage of acceleration signals. The unit was programmed to calculate the sum of the rectified and integrated acceleration curves from all three measurement directions. The time period for integration was set at $1 \mathrm{~min}$ and the finally obtained output from the accelerometer and data unit (AO) was expressed as counts/min. Subjects wore the accelerometer during waking hours.

\section{Results}

In the normal weight subjects, mean ADMR was $12.4 \pm 2.0$ (range 7.9-15.7) $\mathrm{MJ} / \mathrm{d}$, mean SMR was $7.0 \pm 1.0$ (range 5.6-8.9) MJd, and mean Tracmor output, corrected for the influence of transportation (3), was $1108 \pm 293$ (range 5722017) counts/d. Plotting ADMR as a function of SMR (Fig. 1), the residual ranged from -2.3 to $4.8 \mathrm{MJ} / \mathrm{d}$. The residual was closely correlated with Tracmor output (Fig. 2). In a linear regression analysis Tracmor output explained $64 \%$ of the variation in the ADMR adjusted for SMR with a standard error of estimate of $0.9 \mathrm{MJ} / \mathrm{d}$.

With respect to the discrimination between separate levels of daily physical activity, Tracmor values were not significantly different from physical activity levels as quantified by the ratio between ADMR and SMR (PAL= ADMR/SMR), a measure favored by the World Health Organization (15). The PAL intervals recommended by this organization for activity levels with low, moderate,

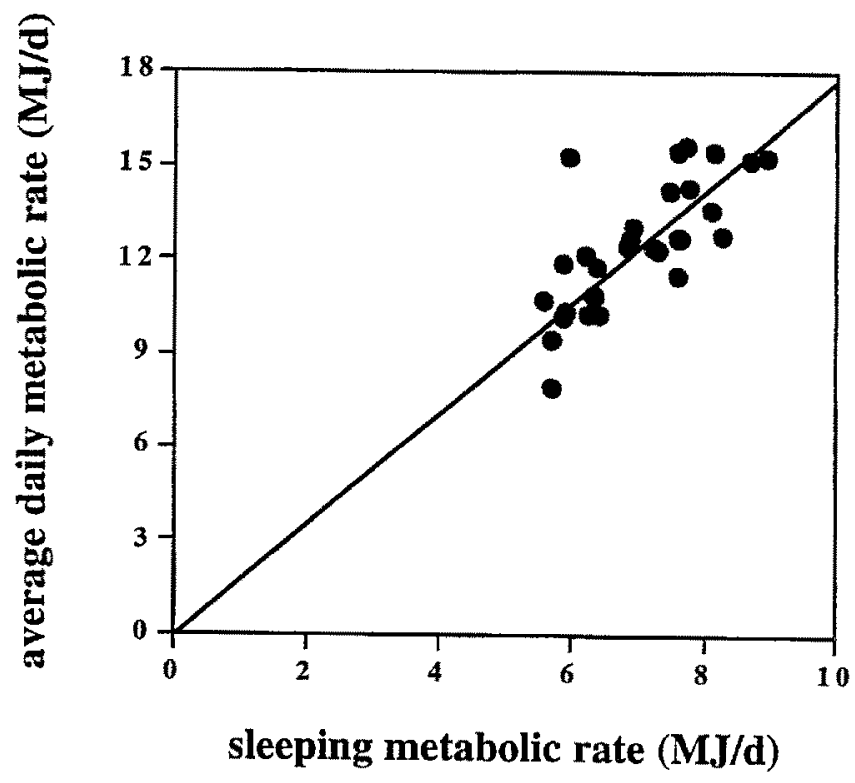

Fig. 1 Average daily metabolic rate plotted as a function of sleeping metabolic rate with the calculated linear regression line in 16 men and 14 women with a normal body weight.

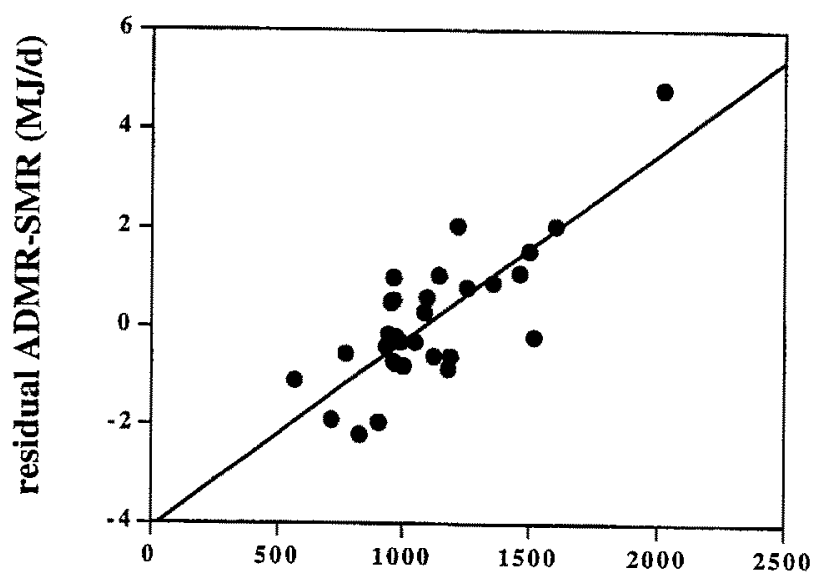

average daily accelerometer output (counts/min)

Fig. 2 The residual of the relationship between average daily metabolic rate and sleeping metabolic rate plotted as a function of average daily accelerometer output with the calculated linear regression line in 16 men and 14 women with a normal body weight.

and high intensity correspond to Tracmor cut-off values of 900 and 1150 counts/min.

Average $\mathrm{AO}$, corrected for the influence of transportation (3), was $1144 \pm 318$ and $946 \pm 391$ for subjects with anorexia nervosa and morbid obesity, respectively, and was not significantly different from the value of $1108 \pm 293$ in normal weight subjects (Fig. 3). However, in the anorectics $\mathrm{AO}$ was significantly related to body 
Fig. 3 Average daily accelerometer output plotted as a function of body mass index in 11 subjects with anorexia nervosa, 30 subjects with a normal body weight, and 8 subjects with morbid obesity.

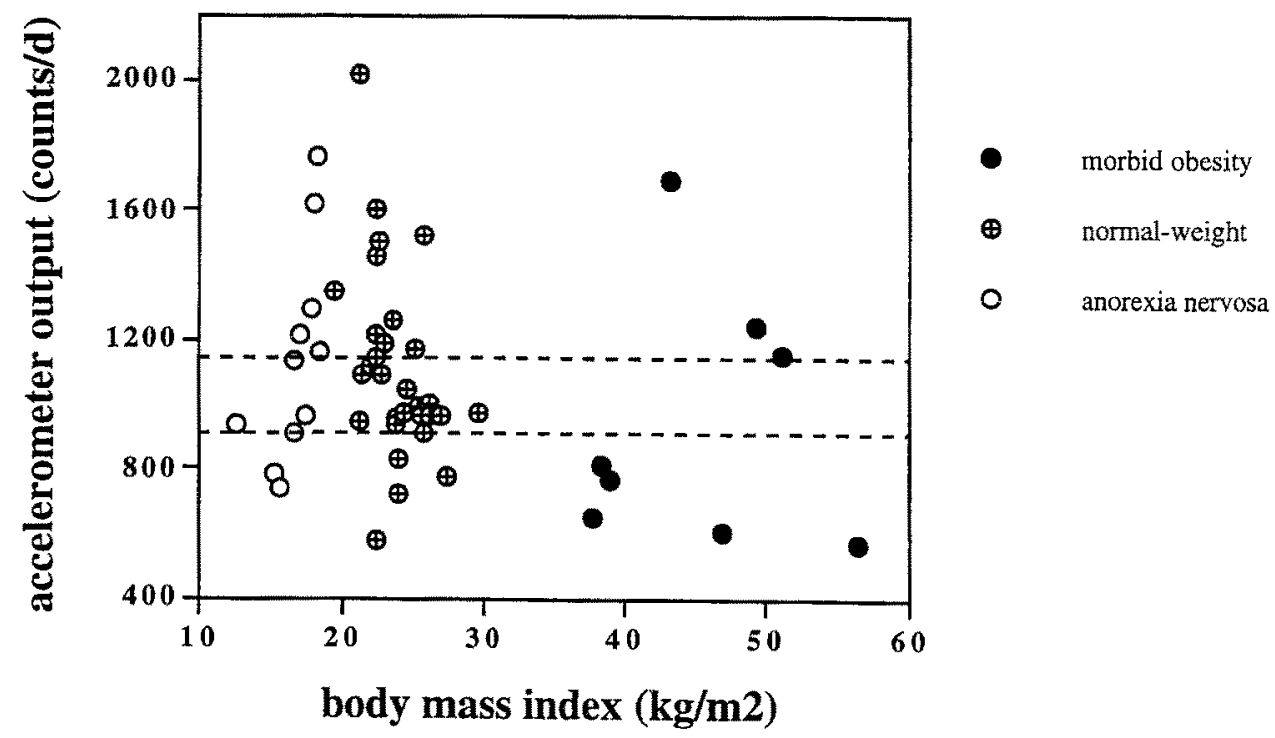

mass index $(\mathrm{r}=0.84, \mathrm{p}<0.01)$, subjects with a $\mathrm{BMI}^{17}$ $\mathrm{kg} / \mathrm{m} 2$ were equally or more active compared with control subjects, while subjects with a BMI $<17 \mathrm{~kg} / \mathrm{m} 2$ were equally or less active compared with control subjects. In the morbid obese group, 5 of the 8 subjects had a low activity level ( $\mathrm{AO}<900$ counts/day), and the other 3 had a high activity level (AO > 1150 counts/day).

\section{Discussion}

The present study was performed to evaluate the use of a Tracmor motion sensor for the assessment of daily physical activity in free-living subjects. This new method was compared with ADMR adjusted for SMR. Using average Tracmor output, corrected for the influence of transportation (3), 64\% of the variation in adjusted ADMR under free-living conditions could be predicted. At least part of the unexplained variation can be ascribed to the performance of static exercise, or movement against external forces (like in pushing or pulling), which result in an increase of energy expenditure without a (proportional) increase in the amount of body movement. Furthermore, missing information about the hours the accelerometer and data unit were not worn, might have affected the prediction. By calculating average weekly Tracmor values it was assumed that these values represent body movement throughout the total 7-day observation period. However, the equipment is often not worn immediately after getting up in the morning until the very moment of going asleep at night, excluding some daily activities. Additionally, subjects told us that the Tracmor was sometimes not worn during intensive sports activities. Despite the shortcomings mentioned, a considerable part of the variation in daily energy expenditure could be predicted and it is expected that improvement of the wearing comfort of the Tracmor will improve the predictability.

When compared to other evaluations of accelerometers under free-living conditions, the field evaluation of the Tracmor showed good results. Correlations between Tracmor output and daily energy measures are generally stronger than those reported for other devices like Caltrac $(r=0.49-0.54(6,9))$. A recently evaluated three-dimensional accelerometer (Tritrac) comparable to the Tracmor significantly underestimated free-living energy expenditure (7).

In the group with anorexia nervosa the results suggest that "paradoxical" overactivity only occurs in subjects with a $B M I>17 \mathrm{~kg} / \mathrm{m}^{2}$ (1). In the group with morbid obesity the level of physical activity was low in the majority of subjects, i.e., 5 out of 8 , as has been shown before (12). The Tracmor appears to be a relatively cheap method to obtain information on the individual activity level.

In conclusion, the triaxial accelerometer is an objective method that can be used to quantify physical activity related energy expenditure and to distinguish differences in activity levels between individuals. 


\section{References}

1. Bouten CVC, Van Marken Lichtenbelt WD, Westerterp KR (1996a) Influence of body mass index on daily physical activity in anorexia nervosa. Med Sci Sports Exerc 28:967-973

2. Bouten CCV, Westerterp KR, Verduin M, Janssen JD (1994) Assessment of energy expenditure for physical activity using a triaxial accelerometer. Med Sci Sports Exerc 26:1516-1523

3. Bouten CVC, Verboeket-van de Venne WPHG, Westerterp KR, Verduin M, Janssen JD (1996b) Daily physical activity assessment: comparison between movement registration and doubly labeled water. J Appl Physiol 81:10191026

4. Carpenter WH, Poehlman ET, O'Connell M, Goran MI (1995) Influence of body composition and resting metabo lic rate on variation in total energy expenditure: a meta-analysis. Am J Clin Nutr 61:4-10

5. Elia M (1991) Energy equivalents of carbon dioxide and their importance in assessing energy expenditure when using tracer techniques. Am J Physiol 260:E75-E88
6. Klesges LM, Klesges RC (1987) The assessment of children's physical activity: a comparison of methods. Med Sci Sports Exerc 19:511-517

7. Matthews CE, Freedson PS (1995) Field trial of a three-dimensional activity monitor: comparison with self report. Med Sci Sports Exerc 27:10711078

8. Rising R, Harper IT, Fontvielle AM, Ferraro RT, Spraul M, Ravussin E (1994) Determinants of total daily energy expenditure: variability in physical activity. Am J Clin Nutr 59:800 804

9. Sallis JF, Buono MJ, Roby JJ, Carlson D, Nelson JA (1990) The Caltrac accelerometer as a physical activity monitor for school-age children. Med Sci Sports Exerc 22:698-703

10. Schoeller DA, Racette SB (1990) A review of field techniques for the assessment of energy expenditure. J Nutr 120:1492-1495

11. Westerterp KR, Brouns F, Saris WHM, Ten Hoor $F$ (1988) Comparison of doubly labeled water with respirometry at low- and high-activity levels. J Appl Physiol 65:53-56
12. Westerterp KR, Saris WHM, Soeters PB, Ten Hoor F (1991) Determinants of weight loss after vertical banded gastroplasty. Int J Obes 15:529-534

13. Westerterp KR, Verboeket-van de Venne WPHG, Bouten CVC, de Graaf $\mathrm{C}$, van het Hof $\mathrm{KH}$, Weststrate JA Energy expenditure and physical activity in subjects consuming full- or reduced-fat diets. Br J Nutr (in press)

14. Westerterp KR, Wouters L, Van Marken Lichtenbelt WD (1995) The Maastricht protocol for the measurement of body composition and energy expenditure with labeled water. Obes Res 3 suppl 1:49-57

15. World Health Organization (1985) Energy and protein requirements. Report of a joint FAO/WHO/UNU Expert Consultation. Technical Report Series no 724 , WHO, Geneva 